\title{
Prezerwatywa, kondom, gumka - o nazwach pewnego środka antykoncepcyjnego i ochronnego w historii polszczyzny
}

\section{Jarosław Pacuła}

Akademia Techniczno-Humanistyczna w Bielsku-Białej paculus@tlen.pl

\section{Streszczenie}

W artykule omówiono funkcjonujace w polszczyźnie nazwy prezerwatywy. Ogladowi towarzyszy perspektywa historycznojęzykowa. Autor przedstawia proces ksztattowania się bogatej synonimii nazewniczej, sięgając do leksyki należącej do różnych rejestrów (odmian) języka. $W$ tekście przywołano ilustracje tekstowe z XV wieku i stuleci późniejszych. Artykut zawiera uwagi zwiąane z etymologia poszczególnych określeń; uwydatnia momenty zapożyczania poszczególnych form i znaczeń z języków obcych.

Stowa kluczowe: historia seksualizmów, nazwy prezerwatywy, językoznawstwo diachroniczne, leksyka historyczna

\begin{abstract}
Prezerwatywa, kondom, gumka - on different names of a certain contraceptive and protective device in the history of the Polish language

In this article the author discusses different names for 'condom' used in the Polish language. The analysis is carried out with the use of methods characteristic of the study of language history. The author presents the development of rich nomenclature synonymy providing the lexical examples from various registers (varieties) of language. The text presents textual examples from the 15th century onwards. The author discusses the etymology of particular words and emphasizes the historical contexts in which words and meanings were borrowed from foreign languages.
\end{abstract}

Keywords: history of sexualities, names of the condom, diachronic linguistics, historical lexis 


\section{Tytułem wstępu}

Przez długi czas słownictwo erotyczne pozostawało poza obszarem dociekań filologicznych, chociaż stanowi ono niezwykle obszerną grupę - ciekawą dla obserwacji leksykologicznych także w perspektywie historycznej. Rozluźnienie obyczajowości oraz wzrost świadomości seksualnej stopniowo łamie dotychczasowy obowiązek tabuizowania erotyki i erotyzmu oraz pozwala wyjść poza stereotypowe komentowanie zjawisk związanych z seksualnością człowieka ${ }^{1}$. Jak pisze Anna Dąbrowska,

[w] Polsce w ciągu ostatnich kilkunastu lat (po 1989 roku) zaszło wiele zmian ekonomicznych, technologicznych, politycznych, społecznych i obyczajowych, które w nieunikniony sposób wpłynęły na zachowania ludzkie. Wynikiem tych przeobrażeń okazało się m.in. kurczenie się niektórych obszarów tabu w kulturze współczesnej (odzwierciedlające się także w języku). Przy czym pojawiają się sytuacje, kiedy zjawiska niepodlegające wcześniej tabu przechodzą do sfery tabuizowanej, co może prowadzić do zaskakujących (i czasem zabawnych) sytuacji. Zmniejszaniu się obszaru tabu sprzyja tzw. kultura obnażania (w sensie dosłownym i przenośnym), przesunięcie granic prywatności, związane choćby z powszechnym posługiwaniem się telefonami komórkowymi, rozpowszechnieniem prasy kolorowej ostro walczącej o czytelników, otwartość mówienia przez osoby publiczne (aktorzy, piosenkarze) o sprawach prywatnych, granicząca czasem z ekshibicjonizmem. Zjawisko to określa się mianem kultury zwierzeń.

(Dąbrowska 2008: 176)²

Kulturoznawcy i socjolodzy coraz częściej zwracają uwagę na fakt, że „cechą kultury nowoczesnej jest powszechna fascynacja seksem” (Giddens [1992]2005: 209). Ta pogoń za szeroko rozumianym ,przeżyciem seksualnym/erotycznym” dotyczy tak realnej rzeczywistości, jak i świata wirtualnego - filmów, gier, treści internetowych, prasy itd. Wydaje się jednak, że „kultura obnażania” rozciąga się daleko poza wizualność, medialną dostępność seksu, powszechność nagości (McNair [2002]2004: 5) - oto jedną z najbardziej widocznych cech współczesnej kultury jest również przekraczanie tabu językowego, stale powiększająca się grupa seksualizmów, a nawet pojawianie się słownictwa religijnego w kontekstach niemających nic wspólnego ze sferą sacrum (Pacuła 2014: 285-312). Wyrazem postępującej seksualizacji kultury, albo inaczej - „pornografizacją kultury szerokiego odbiorcy” (McNair [2002]2004: 31), jest między innymi ciągle rosnąca liczba określeń związanych z antykon- 
cepcją, w tym zwłaszcza środków zapobiegających ciąży i chroniących przed chorobami przenoszonymi drogą płciową.

Wspomniane wcześniej rozluźnienie w sposobie mówienia na tematy dotyczące życia erotycznego nastąpiło w Polsce już w początkach XX wieku; pozostając w kręgu zagadnienia podjętego w niniejszym tekście, wystarczy przywołać kilka reklam prezerwatyw pojawiających się w międzywojennej prasie: Coś dla was Panowie!! Żaden bumbug! Prezerwatywy „Pompea” mówia same za siebie. Dlaczego? P-rzewyższaja wszystkie, jako O-chronny środek, M-iłe w użyciu, P-etna gwarancja, E-lastyczne, A-probowane ogólnie tylko prezerwatywy. [...] Żądać wszędzie („Kurjer Warszawski” nr 126, 1927), „Radio” Gum-prezerwatywy bezprzecznie najlepszej marki światowej. Wszędzie do nabycia! („Nasz Przegląd” nr 117, 1927), ,Olla” - jedyna istniejąca najdoskonalsza marka światowa, udowodniona zupetna gwarancja za każda sztukę („Nasz Przegląd” nr 117, 1927), Najlepsze prezerwatywy „The Gentelman”. Sprzedaż wszędzie. Gwarancja za każda sztukę („Nasz Przegląd” nr 10, 1928), „,Valkyrie” - idealne specjalności hygieniczne. Prezerwartwy Najcieńsze - Najmocniejsze Najtańsze. Gwarancja na każdej sztuce („Kurjer Warszawski” nr 14, 1928), Jak jedwab delikatne, jak żelazo trwałe, jedynie tylko „Olla” sa tak doskonate” („Nasz Przegląd” nr 123, 1930), Nie czyńcie eksperymentów ze zdrowiem. Nie dajcie się na nic innego rzekomo równie dobrego namówić. „Olla” to marka wypróbowana w ciąu dziesiątków lat. Także antyseptycznie spreparowane („Nasz Przegląd” nr 166, 1931), Zdrowie to skarb! „Primeros” prezerwatywy antyseptycznie spreparowane to gwarancja zdrowia. Wystrzegać się naśladowników! („Głos Poranny” nr 167, 1931), 100\% pewna prezerwatywa! „Ultra” - dajemy Panu możność przekonania się o doskonałości prezerwatyw („Głos Poranny” nr 167, 1931), Zdrowia strzega przed choroba trwale, a cienkie prezerwatywy Yo-Yo GUM... (,Nasz Przegląd Ilustrowany” nr 6, 1933), Choć jest kryzys, choć jest bieda, lecz bez „Olla” żyć się nie da! („Głos Poranny” nr 62, 1936). Mało tego, zagadnienie otwarcie poruszały ówczesne poradniki:

W ostatnich dziesiątkach lat została znajomość szczególnie kiły i opierające się na niej leczenie znacznie udoskonalone. Ale ani odkrycie zarazka kiły [...], ani udoskonalenie metod rozpoznawczych [...], ani wzbogacenie metod leczniczych [...] nie będą mogły naprawdę opanować kiły, dopóki nie uda się wstrzymać ciągłego dopływu nowych zakażeń. Stać się to może tylko przez zapobieganie, którego głównem wymaganiem jest stosowanie bez wyjątku środków ochronnych - najlepiej [...] kondomu z błony zwierzęcej (błony rybiej) - przy każdym stosunku płciowym, nie mającym na celu zapłodnienia. Kategoryczne żądanie unikania jakiegokol- 
wiek stosunku pozamałżeńskiego nie jest wystarczające. Doświadczenie bowiem wszystkich narodów i czasów uczy, że tylko bardzo mały procent mężczyzn chce i może powstrzymać się od stosunku płciowego i to aż do czasu, być może, późnego małżeństwa. To doświadczenie powinnoby się stosować także do dojrzałych płciowo, a wolnych mężczyzn [...]. Nad tak ogólnie bowiem sprawdzonem doświadczeniem psychologji mas nie może przejść higjena do porządku dziennego, lecz musi dostosować swoje wnioski do przeciętnej psychicznej odporności normalnego mężczyzny względem popędu płciowego. Takim wnioskiem jest żądanie używania kondomów. Używanie kondomu nie powinno być czynnością tylko wyjątkowej rozwagi, lecz powinno stać się ogólnie zrozumiałym zwyczajem we wszystkich wypadkach, w których nie można wyłączyć niebezpieczeństwa zakażenia się. Pytanie dopuszczalności lub niedopuszczalności stosunków pozamałżeńskich nie ma z poleceniem używania środków ochronnych nic wspólnego [...].

(Grotjahn 1930: 121)

W dalszych partiach tekstu zaprezentowane zostaną określenia ,środka antykoncepcyjnego dla mężczyzn w postaci osłonki z cienkiej gumy nakładanej na prącie” (USJP). Na zagadnienie seksualizmów nazywających wspomniany desygnat spojrzano z perspektywy diachronicznej, stąd też liczne w wywodzie odniesienia i do słowników współczesnych, i do opracowań historycznych. Seksualizm rozumiany jest przy tym jako ,wyraz lub frazeologizm określający treści dotyczące sfery seksualnej, charakterystyczny dla słownictwa odnoszącego się do spraw seksu (płci, płciowości)" (Dubisz 1999: V). Podstawę materiałową stanowi kilkanaście leksemów, które wyekscerpowano z leksykonów, ale też z tekstów umieszczonych w przestrzeni internetowej.

\section{Krótko o długiej historii prezerwatywy}

Już w cywilizacjach starożytnych poszukiwano sposobów na zapobieganie ciążom i chorobom wenerycznym (np. Egipcjanie używali cienkich płatów papirusa), jednak dopiero w XVI wieku, a więc w okresie szerzenia się w Europie syfilisu, pojawiły się środki zbliżone do dzisiejszych prezerwatyw - były to lniane woreczki, które nasączano solami nieorganicznymi. W dwóch następnych stuleciach osłonki takie wytwarzano ze zwierzęcych jelit. Niektórzy badacze twierdzą jednak, że pomysł ten wykorzystywali już starożytni Grecy i Rzymianie. W pierwszych dziesięcioleciach XIX wieku (w 1837 r.) Charles Goodyear opatentował i wprowadził do produkcji pierwszą gumową prezerwatywę - wpierw wielokrotnego użytku i pokaźnej grubości, wkrótce jednorazowych i cienkich. W historii prezerwatywy zna- 
leźć można również rodzimy akcent - w 1916 roku Julius Fromm, mieszkający w Niemczech polski Żyd, opatentował metodę produkcji bezszwowych prezerwatyw z lateksu, które w dwudziestoleciu międzywojennym podbiły świat (jeszcze przed wybuchem drugiej wojny światowej popyt na produkt wynosił nawet 70 milionów sztuk rocznie).

W historii prezerwatywy znajduje odbicie powszechnie znana prawda: potrzeba matką wynalazków. „Potrzeba” (jakkolwiek ją tutaj rozumieć) dotyczyła przede wszystkim mas, więc nie dziwi fakt, że to właśnie starożytni hodowcy bydła i rybacy wprowadzili wynalazek - z powodzeniem wykorzystywali jelita owiec i pęcherze pławne ryb. W następnych latach jedynie udoskonalano przedmiot. Niemniej jednak cały czas, bo jeszcze w początkach XX wieku, „naturalne nakładki” stanowiły alternatywę dla opatentowanych w 16. stuleciu przez medyków i stosowanych $\mathrm{z}$ reguły w wyższych sferach płóciennych nakładek wielokrotnego użytku (przede wszystkim w celu zabezpieczenia przed chorobami).

Szerzej kwestię historii prezerwatywy omawiają prace Aine Collier (2007), Kamila Janickiego (2015) i Henry’ego Youssefa (1993: 226-228).

\section{Opis poszczególnych leksemów}

\section{1. prezerwatywa}

Najstarszymi polskimi określeniami używanego przez mężczyzn środka antykoncepcyjnego, chroniącego również przed zarażeniem się chorobami wenerycznymi, są prezerwa i prezerwatywa. Wyrazy te, choć notowane w staropolszczyźnie, w obecnym znaczeniu pojawiły się znacznie później, w wyniku zawężenia znaczenia, które nastąpiło prawdopodobnie pod wpływem francuszczyzny. Prymarnie bowiem posiadały sensy: (a) 'zabezpieczenie, ochrona' i (b) 'lekarstwo'. W tych właśnie znaczeniach, przejętych z łaciny średniowiecznej (łac. praeservativum $\leftarrow$ praeservare 'zachowywać' $\leftarrow$ pre-/prae- 'przedrostek: przed, w przód, najpierw, bardzo' + servare 'chroniący, broniący'), odnotowują go najwcześniejsze słowniki Thesaurus Knapiusza z 1621 roku oraz Nowy dykcyonarz Trotza z 1764 roku: „Prezerwa / [...] Præferuans medicamentum: præfidiarium medicamentum [...] (KNAP), Prezerwa. ein Präfervativ, prefervatif, un rémede qui préferve (TROTZ). Odnieśmy się do kilku ilustracji tekstowych z XVI, XVII i XVIII wieku:

a iefli o powietrze idzie/ bierz prezerwátywy/ thedyć fie bać nie trzebá.

(SXVI: Ł. Górnicki, Dworzanin polski, Kraków 1566) 
Amuletum - Preserwatiwa przecziwko trucziznie.

(SXVI: A. Calepinus, Dictionarium decem linguarum, b.m.w. 1588)

A też do tego Sákrámentu/ nie prace álbo zabáwy przefzkadáią [...] ále fáme grzechy/y to iefzcże śmiertelne tylko. Dobrze też y ná te zabáwy/ iáko zarázy cżáfem fumnienia ludzkiego/ y duchowne iákieś powietrza/ bráć iákie lekárftwa/ y preferwátywy. ná co fię pewnie zdobędżie/ ktory nád tym nabożeńltwem trochę vśiędżie.

(SXVI: M. Laterna, Harfa duchowna, Kraków 1588)

á Sácrcament [!] Pańlki gwałtem mu [umierającemu] w vftá tkáią. Cżemu? Aby práwi Szátan do niego práwá nie miał [...]. Ták ieft/ nie ledá to praeferuatiua iáko zá zdrowia/ ták y w chorobie/ przy śmierći náwet Swiątośći Pańlkie.

(SXVI: P. Artomius, Tanatomachia, to jest bój z śmiercia, Toruń 1600)

Ktoby nosił z niego [kopytka] Krzyżyk ábo pierścionek ná Szyiey/ od tey choroby y czárow/ będzie miał prezerwátywę.

(SXVII: S.K. Herka [Hercius], Bankiet narodowi ludzkiemu [...] zgotowany, Kraków 1660)

Serdeczny tylko palec dwa pierścionki nosi. Gwoli prezerwatywom: bawoli i łosi.

(SXVII: A. Korczyński, Wizerunek złocistej przyjaźniq zdrady, Kraków 1698)

Scillę, alias cebulę Dioscorides medyk przeciw czarom we drzwiach radzi zawiesić, a Pliniusz radzi skórę z głowy albo pysek wilczy nade drzwiami lokować dla prezerwatywy od czarów. [...] Aristoteles tęż moc Rucie przyznaje.

(SXVII: J.B. Chmielowski, Nowe Ateny Albo Akademia Wszelkiey Scyencyi Petna [...], Lwów

Naylepsza prezerwatywa w katarowych przypadkach spokoyne od wszelkich passyi y agitacyi utrzymanie się.

(SXVII: J.J. Jelonek [Cervus], Medyk domowy Samuela Beimlera nauczający domowemi i mało kosztującemi lekarstwy [...], Leszno 1749)

We wspomnianych sensach wyraz prezerwatywa notują jeszcze SL (wyd. w 1. 18071814), SWIL (wyd. 1861 r.) i SW (wyd. w 1. 1900-1927): 'zapobieganie, uchowanie' SL 'zapobieżenie, ochrona, środek' SWIL, 'środek zapobiegawczy, ochronny’ SW. Jednocześnie wszystkie trzy słowniki przytaczają formę synonimiczną - prezerwa, ale tylko SWIL i SW 
z zaznaczeniem, że jest ona archaiczna. Co jednak ważne, to właśnie SW (t. 4. z 1908 r.) po raz pierwszy przy prezerwa oraz prezerwatywa podaje definicję 'osłonka prącia'.

Uwzględnione w SW zawężenie znaczenia słowa znanego staropolszczyźnie (będącego pożyczką łacińską i mającego szeroki zakres semantyczny) dokonało się pod wpływem języka francuskiego, w którym to préservatif ( $\leftarrow$ préservation 'chronić') już w 1567 r. jest definiowane eufemistycznie jako 'to, co uchowuje od zła moralnego' (ce qui préserve d'un mal moral), ale już w 1857 r. wprost nazywa osłonki zakładane przez mężczyzn na penisy (DAF, TLF) ${ }^{3}$. Warto jednak zauważyć, że Słownik wyrazów obcych Arcta z 1886 roku nadal wzmiankował słowo jako ogólnikowe miano zaczerpnięte z łaciny: „Prezerwatywa ł. środek zapobiegający, ochronny" (SwOA), a co ciekawsze, podobna informacja pojawiła się w wydanym w 1939 r. przez Trzaskę, Everta i Michalskiego Encyklopedycznym słowniku wyrazów obcych: „Prezerwatywa, n.-ł., zapobieganie, środek ochronny” (Eswo).

Oto kilka ilustracji zaczerpniętych z opracowań medycznych i paramedycznych, obrazujących współwystępowanie prymarnego i wtórnego znaczenia od drugiej połowy XIX wieku:

Uczynić tu nam przychodzi niechcącym pewną praktyczną uwagę, podczas [...]: że kamfora truje pajączki zaraźliwe roznoszące cholerę po powietrzu, stronnicy jego szarlataństwa, pragnąc niby ochronić swych pacyentów od nieszczęścia dusili ich zapartych w kamforycznej atmosferze - a przecież do nich tak jak i tam gdzie niekurzono kamforowych cygar, womit, laksa i kurcze śmiertelne przyszły. Toż samo się działo z choleryną i resztą nakadzań wszelkich, do zabicia miazmatu epidemicznego używanych zewsząd - wypada zatym wnosić, że jedne tylko sucho utrzymane, wielą osobami niezapchane, przestrone izby w których codziennie po kilka się razy odnawia świeże powietrze, zdają się czynić przeciw zarazie téj prezerwatywę jak najlepszą. Tak wszędzie ludzie niewiedzący że grzeszą, dopuszczają się nadużyć smutne za sobą pociągających rezultaty.

(Polkowski 1853: 28)

Te same lekarstwa, które symptomom każdej cholery najwięcej odpowiadają, mogą także służyć jako prezerwatywa i ochrończy środek.

(Dłużniewski 1855: 4)

Bardzo dobroczynnym ukazał się sok z ziół styryjskich u osób skłonnych do katarów podczas dżdżystej pory i mgły jesiennej, zalecić go zatem można jako prezerwatywę, aby czasami trochę z flaszeczki przy sobie mianej zażywać, osobliwie osobom podróżującym w czasie ostrej pory jesiennej i zimowej. 
(Raudnitz 1865: 10)

PREZERWATYWA, PREZERWA $=$ środek, lek ochronny. $-\mathrm{P}$-wa $=$ kondom.

(Giedroyć 1933: 121)

Nowy sens wyrazu, jako jedyny (!) odnotowują dopiero opracowania z drugiej połowy $\mathrm{XX}$ wieku: 'środek antykoncepcyjny używany przez mężczyzn, osłonka z cienkiej gumy zapobiegająca zapłodnieniu kobiety, zmniejszająca niebezpieczeństwo zakażenia chorobami wenerycznymi’ SDoR, 'środek antykoncepcyjny dla mężczyzn w postaci osłonki z cienkiej gumy nakładanej na prącie’ USJP, 'środek ochronny, zwłaszcza przeciw zarażeniu chorobami wenerycznymi albo AIDS lub antykoncepcyjny; kondom' SwoK, 'osłonka z cienkiej gumy zakładana na prącie przed stosunkiem płciowym, będąca mechanicznym środkiem antykoncepcyjnym zapobiegającym przedostaniu się plemników do dróg rodnych kobiety, równocześnie zmniejszającym zagrożenie zakażenia chorobami przenoszonymi drogą płciową, np. AIDS; kondom' SwoE, 'gumowa osłonka zakładana na członek przed stosunkiem płciowym - jako środek antykoncepcyjny i jako zabezpieczenie przed chorobami przenoszonymi drogą płciową' MswoIT, WswoIT. W NKJP znajdziemy między innymi takie jego ilustracje:

Mieli tu też saunę i siłownię. Firma oferowała hiszpańskie, rzymskie i francuskie masaże w cenie od osiemdziesięciu do stu trzydziestu złotych za godzinę. Możliwy był też masaż z udziałem dwóch panienek w pokoju lustrzanym. Obowiązkowa kąpiel i prezerwatywa... Na parterze dudniła muzyka, obok barek i sala bilardowa.

(NKJP: M. Miller, Pierwszy milion czyli Chopcy z Mielczarskiego, Warszawa 1999)

[...] rozkładam nogi w fotelu. Wywiad: - Wiek? - Trzydzieści sześć lat. - Tabletki antykoncepcyjne? - Nie. Nie mogę, nadciśnienie. - Inne środki? - Od tylu lat znam swój organizm... wiem, kiedy jajeczkuję, w płodne dni prezerwatywa. - Ciąże? Aborcje? - Nie. - Problemy? Żadnych. Wszystko powinno być w porządku. Mam jednak złe przeczucie.

(NKJP: M. Gretkowska, Polka, Warszawa 2001)

„Trzecie miejsce zajął Jerzy Toptiński. Mimo przejmującego chłodu i niesprzyjających warunków amatorzy tenisa po letniej przerwie tłumnie przybyli na korty przy ulicy Bażyńskiego. W imprezie..." Wtedy poczułem, że zsuwa mi się prezerwatywa... Ja tego nie słyszałem w szale miłości, na takie rzeczy nie zwraca się uwagi... „...łączymy się z salą posiedzeń w Magdalence...”. Zanikała muzyka, czasami mówił rzecznik rządu, czasami Wałęsa. Orgazm. 
(NKJP: W. Stamm, Czarna matka, Warszawa 2008)

Dziewczyna podała mu opakowanie z napisem „Black XXL”. Kiedy Pater płacił i niezgrabnie wciskał prezerwatywy do małej kieszonki w dżinsach, usłyszał znajomy śmiech.

(NKJP: M. Krajewski, M. Czubaj, Róże cmentarne, Warszawa 2009)

\section{2. kondom/kondon}

Wyraz prezerwatywa jest nazwą oficjalną, należącą do rejestru języka literackiego. Połowa XIX wieku przynosi jej synonimy: kondom i kondon. Ich istnienie sugeruje poradnik dla mężczyzn z 1843 roku, ale - nie wiedzieć dlaczego - sam autor nimi nie operuje:

Już oddawna zalecono używanie rozmaitych środków mechanicznych, celem zabezpieczenia się od zarazy syfilitycznéj, lecz te jako bezskuteczne, mniej zasługują na powszechną uwagę. Jeden tylko z nich dzisiaj znacznie upowszechniony, stał się przedmiotem handlu, szczególniéj w wielkich miastach europejskich. Mowa tu jest o znanych powszechnie delikatnych woreczkach, z błony brzusznéj niektórych zwierząt ssących, albo téż z błon czyli pęcherzów rybich, których wyrabianiem w Anglii i we Francji zatrudniają się teraz osobne fabryki. Tych woreczków noszących podobno, jak Girtanner twierdzi, nazwisko wynalazcy, zaczęto najprzód używać w Anglii w drugiej połowie 17 wieku, za panowania Karola II (zaznaczenie - J.P). Woreczki z błon rybich są daleko lepsze od tych, które zwykle z błon brzusznych wyrabiają: albowiem tamte będąc w całości, bez sztucznego spojenia, są mocniejsze, te zaś są wzdłuż sklejone i dla tego podczas użycia za przystępem wilgoci częstokroć się psują. Używają ich mężczyźni podczas spółkowania do powleczenia członka, w celu zabezpieczenia się od zaszczepienia jadu syfilitycznego. Doświadczenie jednakże przekonywa, że te woreczki są bardzo niepewnym środkiem ochraniającym. Przez najmniejszy bowiem otworek; powstały najczęściéj w razie rozdarcia albo rozklejenia się woreczka podczas spółkowania, jad syfilityczny zwykł się zaszczepiać z największą łatwością. Prócz tego jad syfilityczny dostać się może do worka jądrowego i innych przyległych części, których zazwyczaj użyty woreczek nie pokrywa. Dziwić się trzeba, że w wielu wzorowo nawet urządzonych krajach europejskich, policya nie zabrania fabrykacji, lub téż sprowadzenia z zagranicy tych woreczków, które bynajmniéj nie są środkiem dostatecznie zabezpieczającym od zaszczepienia się jadu syfilitycznego.

(Rosenblum 1843: 164-165)

SWIL odnotowuje wyłącznie drugą z form - kondon 'obsłona w kształcie woreczka z pęcherzyny, obwójka', podobnie jak opracowanie Jana Karłowicza z 1895 roku (SwoKA). 
Jednak liczne zniekształcenia leksemów pod wpływem wyrazów zakończonych na -on nie wykluczają istnienia wówczas postaci kondom (Bańko 2003). Jest to tym bardziej prawdopodobne, że już w SW funkcjonują obie formy: kondon i kondom 'obsłona w kształcie woreczka bez szwu, z kiszki ślepej baraniej i t. p. sporządzona, woreczek chirurgiczny i antysyfilityczny, obwójka, woreczek bezpieczeństwa’. Odnieśmy się do kilku najwcześniejszych ilustracji tekstowych, zaczerpniętych z tekstów popularnonaukowych i naukowych:

$\mathrm{Z}$ innych przedmiotów znajdywano w pochwach: flaszkę z wody kolońskiej, lub inne flaszki, rączkę od żelazka prasowalnego, penzel golenny, gładyszki (kostki do gładzenia), marchewkę, pieruszkę, świeczki lub świece, kiełbaskę (wirstel), sardelkę, różaniec, śpilki włosowe, wiązak (sznurek), igielnik pusty lub z igłami, włosie końskie, woreczki (kondomy), gąbki ochronne (safety-sponges), i t. p. najrozmaitsze przybory, narzędzia lub przedmioty. Wiele takich przedmiotów zostaje setki razy u tysięcy kobiet wprowadzanymi, i udaje się sztuka - czyli nie zachodzi potrzeba pomocy lekarskiej; ale od czasu do czasu zechce ,pech”, że zajdzie potrzeba lekarza - i temu wówczas usta się z podziwu otwierają: czego bo już ludziska dla zaznania błogości płciowej nie użyją za samidło, i na jakie już pomysły nie wpada ludzka - tak męska jak kobieca - wyobraźnia.

(Kurkiewicz 1906: 469)

Kondom jest osłoną, którą okrywa się członek męski przed spółkowaniem. Rozróżniamy „kondom gumowy”, sporządzony z gumy, gutaperki, kauczuku i „kondom koekalowy”, sporządzony z błony śluzowej odbytnicy kóz albo owiec. [...] Kondom jest „powszechnym środkiem ochronnym" t. zn. chroni przed tryprem i syfilisem, o ile ten - co się najczęściej zdarza - przeniesiony zostaje z części płciowych. Wszyscy wybitni specjaliści chorób wenerycznych są zgodni w tem, że kondom [...] jest najlepszym i najpewniejszym ze wszystkich środków ochronnych, [...]. Może w prawdzie być używany tylko przez mężczyznę, chroni jednak równocześnie i kobietę przed zarażeniem się tryprem, nierzadko także przed infekcją luetyczną (syfilityczną).

(Bloch 1929: 241)

Najważniejszym środkiem prewencyjnym, poprostu mówiąc, właściwym środkiem prewencyjnym jest kondom. Jest nim już dlatego, gdyż znajduje zastosowanie u mężczyzny, który jest seksualnie czynną, a przeto za następstw a odpowiedzialną stroną. Kondom składa się z cieniutkiej, do kształtu członka dopasowanej osłonki, która zapobiega dostaniu się nasienia do przyrządów rodnych kobiety. [...] Istotnie znajdujemy w kondomie z błony jelitowej jedyny środek zapobiegający zapłodnieniu, a odpowiadający wszelkim wymogom i dlatego zasługuje 
on przedewszystkiem na polecenie ze stanowiska medycyny, higieny i eugeniki [...]. Co więcej, używanie go jest zarazem jedynym pewnym i niezawodnym środkiem przeciwko zarażeniu się chorobami wenerycznemi. Nie ulega najmniejszej wątpliwości, że straszliwa plaga chorób wenerycznych znikłaby zupełnie w ciągu niewielu dziesiątek lat, gdyby każdy stosunek, nie zmierzający do spłodzenia potomstwa, odbywał się przy użyciu kondomu. Środek ten odpowiada dwóm ważnym wskazaniom, mianowicie, po pierwsze, chroni przed zakażeniem, a po drugie, przed niepożądanem potomstwem.

(Grotjahn 1930: 56)

KONDOM, KONDON (niewłaściwie: nazwisko wynalazcy: Condom) = baudruche, Praeservatif

(Giedroyć 1931: 312)

Jak sugeruje ostatni z przytoczonych cytatów, interesujące jest pochodzenie nazwy kondom. Niewątpliwie leksem ten jest pożyczką z angielszczyzny (condome) ${ }^{4}$. Informację taką odnotowują: USJP, SDoR, SwoK, SwoE, SwoKA, WswoIT, SzA, przy czym wszystkie opracowania wzmiankują o możliwym (a więc niepewnym) związku wyrazu z nazwiskiem angielskiego medyka, któremu przypisuje się wynalazek prezerwatyw - hrabiego Condoma/ Condona, służącego na dworze króla angielskiego Karola II $^{5}$. Sugestię, że kondom jest eponimem, znaleźć można już w SW. Etymologię tę należy jednak uznać za błędną, wszak nie ma dowodów na istnienie takiej osoby, a co więcej - prezerwatywy były wykorzystane w Anglii znacznie wcześniej, ponad sto lat przed wstąpieniem Karola II na tron, czyli przed 1530 rokiem (Cryer 2014: 39). Takiemu pochodzeniu zaprzeczył William E. Kruck, amerykański językoznawca, który w 1981 roku opublikował tekst o znamiennym tytule - Szukając dr. Condoma (Looking for Dr. Condom). Artykuł nie przyniósł jednoznacznej odpowiedzi w sprawie pochodzenia internacjonalizmu kondom 'prezerwatywa' (Kruck 1981: 1-105, por. Youssef 1993: 226-228), ale udało się Kruckowi podważyć również dwie inne teorie na temat pochodzenia słowa: (a) obalił teorię Hansa Ferdy’ego z 1908 r., wedle której nazwa condom powstała na cześć wsi położonej w południowej Francji ${ }^{6}$, (b) zaprzeczył też tezie Paula Richtera z 1911 r. o egzotycznym pochodzeniu słowa (perskie kondü lub kendü). Dodać wypada, że większość angielskich słowników do dziś przy haśle condome umieszcza informację o niepewnej etymologii wyrazu (por. np. OETYMD, CED).

Bardziej wiarygodna jest wersja o łacińskim pochodzeniu wyrazów kondom/ kondon, choć i w tym przypadku trudno o jednoznaczność. Otóż mogą się one wiązać z dwoma słowami: bądź to condus 'zbiornik, naczynie na ciecz; pochwa; schowek' ( $\leftarrow$ condere 'wy- 
pełniać, ukrywać, chować') bądź condomare 'kontrolować, ograniczać'. Na inne łacińskie źródło wskazuje antropolog języka i teolog Zacharias P. Thundy - łączy on wyraz kondom (condom) z morfemami con 'with' i doma 'roof' lub dome 'dach, kopuła' (1985: 177-179). Na łaciński źródłosłów wskazuje także historyk Aine Collier w opublikowanej w 2007 roku pracy Niepozorna mała prezerwatywa (The Humble Little Condom), przy czym proponuje ona związanie wyrazu kondom z cumdum, które wpierw posiadało sens 'pochwa, futerał broni siecznej, noża itp.' (2007: 71). W podobnym duchu wypowiada się również niemiecki językoznawca Wolfgang Mieder (1987: 99-108).

\section{3. guma, kalosz, kapturek}

Bogaty repertuar nazw prezerwatywy notuje polszczyzna potoczna, przy czym niemały udział w ich powstaniu mają socjolekty (zob. Przybylska 1987: 97-109). Poza powszechnie znanymi określeniami, występującymi także w słownikach ogólnych polszczyzny: kondon (MSSIMP, SGU, SSP, SPLP), kondom (MSSIMP, SGU, SSP, SPLP), guma (SPLP, EINT, SPP, SSP, SPLP), gumka (SPLP, MSSIMP, SPP, SSP, SPLP), dominują wśród nich neosemantyzmy, „określenia metonimiczne, niekoniecznie eleganckie" (Dąbrowska 1998: 81). Są to przede wszystkim określenia odsyłające do odzieży, zwykle funkcji pełnionej przez jakąś część garderoby, jej wyglądu lub materiału, z jakiego jest wykonana: kapelusik (SGU; prymarnie 'nakrycie głowy składające się zwykle z główki i ronda'), kapturek (SGU, SSP, SPLP; prymarnie 'nakrycie głowy w kształcie stożka, połączone z wierzchnim ubraniem') (zob. Kołodziejek 2005: 186), płaszczyk (SGU, SSP; prymarnie 'wierzchnie okrycie sięgające kolan lub dłuższe, noszone dla ochrony przed zimnem lub deszczem'), gumiak (MSSIMP; prymarnie 'but gumowy'), mundurek (SGU), kalosz (SSP; prymarnie 'gumowy but z cholewką'), rękawiczka (SGU; prymarnie 'okrycie dłoni noszone głównie dla ochrony przed zimnem'), czapka (SGU; prymarnie 'nakrycie głowy bez ronda'), czepek/ czepeczek (SSP, SPLP; prymarnie 'nieprzemakalne nakrycie głowy, używane w czasie kąpieli; w ogóle: mała czapeczka’), skafander (np.: http://www.podrywaj.org/forum/prezerwatywa_kilka_pytan_do_fachowcow [14 XI 2017]; prymarnie 'kurtka z kapturem, chroniąca przed wiatrem i opadami; szczelny, odpowiednio wyposażony ubiór, umożliwiający człowiekowi przebywanie w środowisku, do którego warunków nie jest przystosowany organizm ludzki'), kombinezon (SGU; prymarnie 'jednoczęściowe ubranie, będące połączeniem bluzy ze spodniami'), skarpeta (SSP; prymarnie 'okrycie stopy sięgające powyżej kostki lub do połowy łydki').

Rzadsze są miana nawiązujące do wyglądu i funkcji obiektów innych niż odzież, zwykle związanych z ochroną, zabezpieczeniem: bezpiecznik (ŻK, EINT; prymarnie 'urzą- 
dzenie zabezpieczające przed skutkami nadmiernego obciążenia instalacji elektrycznej; urządzenie zabezpieczające mechanizm przed skutkami nadmiernego obciążenia mechanicznego'), uszczelka (np: http://www.insomnia.pl/Prezerwatywa-t183546.html [14 XI 2017]; prymarnie 'element z plastycznego lub sprężystego materiału do wypełniania szczelin pomiędzy częściami jakiegoś urządzenia'), nakladka (SGU, EINT; prymarnie 'materiał, tworzywo nakładane w jakiejś formie na inne materiały, przedmioty itp.; też: przedmiot, przyrząd nakładany na coś'), szpaler (EINT; prymarnie 'równoległe szeregi ludzi tworzące korytarz służący jako przejście podczas różnych uroczystości'), osłonka (SGU, EINT; prymarnie 'ochronna warstwa lub cienka, błoniasta tkanka u zwierząt, osłaniająca niektóre komórki; zewnętrzna powłoka wędlin'), okucie (SSP; prymarnie 'metalowe, często ozdobne umocnienie drewnianych przedmiotów'), kordon (SGU, EINT; prymarnie 'ciasny szereg lub kilka szeregów żołnierzy, policjantów itp. otaczających jakiś obiekt lub blokujących przejście'), kokon (np.: https://fotka.com/grupa/744706/Gimnazjum_c_LO_d/Blog?strona=8 [14 XI 2017]; prymarnie 'powłoka wytwarzana przez larwy niektórych owadów, w której rozwijają się one i przepoczwarzają w dorosłą postać, osłonka otaczająca jaja niektórych zwierząt, stanowiąca ochronę przed zagrożeniami z zewnątrz'), tama (SGU, EINT; prymarnie 'zapora wodna wznoszona przy regulacji rzeki'), zakapsel (STGP; por. kapsel 'zamknięcie szklanej butelki zapewniające szczelność'), balon (SPLP, SsP; prymarnie 'statek powietrzny bez napędu, składający się z kulistej powłoki wypełnionej gazem lżejszym od powietrza i z zawieszonej pod nią gondoli; przedmiot z cienkiej, rozciągliwej i kolorowej gumy, wypełnianej powietrzem, służący do zabawy lub dekoracji'), opona (SsP; prymarnie 'gumowa obręcz stanowiąca zewnętrzną część koła pojazdu'), ogumienie (MssıMP, SsP; prymarnie 'opony gumowe kół pojazdu').

Oprócz wspomnianych już określeń sytuują się wulgarne neologizmy: jebadto (SPP), jebadetko (SPP), nahujnik/nachujnik (np: www.fabrykamemow.pl/memy/324463 [14 XI 2017], http://joemonster.org/phorum/read.php?f=30\&t=150000 [14 XI 2017]), fiuteral (np.:

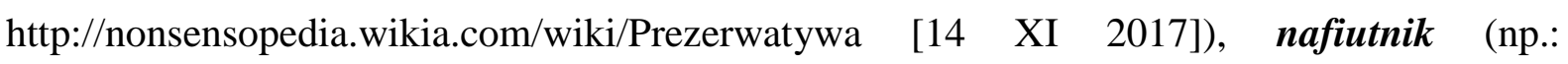
http://forum.gazeta.pl/forum/w,384,29450216,29450216,PREZERWATYWA_jak_inaczej_.h tml [14 XI 2017]). Trzeba przy tym zaznaczyć, że takich ordynarnych, kakofemistycznych nazw jest niewiele, a jeśli już się pojawiają, to jednostkowo, okazjonalnie.

Zdarzają się też nazwy oparte na grze językowej, czy to związanej z sensami poszczególnych komponentów w określeniach będących wyrażeniami, jak glowica jądrowa (np.: „Dekada Literacka” nr 4, 1994; głowica jądrowa 'głowica bojowa rakiety, bomby, torpedy itp. zawierająca ładunek jądrowy', przy czym: głowica 'cała prezerwatywa lub znajdująca się 
na jej końcu wypustka na nasienie' 'górna lub końcowa, kulista część jakiegoś przedmiotu', jądrowa 'związana z męskim gruczołem rozrodczym wytwarzający plemniki' 'centralna część atomu'), gumka na ucho (SSP; ucho to żartobliwe, eufemistycznie miano członka) i ochraniacz na lufe (SSTP; lufa to potoczne, przenośne określenie członka), czy to wynikającej z podobieństwa brzmieniowego wyrazów, jak prezes (MSSIMP, SGU, SSP) i prezeska $(\mathrm{SGU}) \leftarrow$ prezerwatywa. Na marginesie warto wspomnieć, że podobieństwem graficznym i fonetycznym może być wsparte pojawienie się niektórych wspomnianych już nazw: kordon/ kondorl kokon-kondon, fiuterat-futerat/fiut.

Są jeszcze dwie nazwy, o których należy wspomnieć. Pierwsza z nich to eros (SPLP, SSM, SGU, SPP, EINT). Jej pojawienie się w polszczyźnie wiąże się z okresem PRL-u, kiedy to na rynku pojawiła się popularna marka prezerwatyw produkowanych przez krakowską firmę Stomil, zresztą nawiązująca do mitycznego boga miłości - Erosa. Szybko jednak nastąpiła apelatywizacja nazwy i zaczęto jej używać jako eufemistyczne miano prezerwatyw w ogóle. Ze wspomnianym tu producentem wiąże się zresztą druga nazwa, o której wspomina Jacek Lewinson w Słowniku seksualizmów polskich-stomilek.

W zgromadzonym materiale uwagę zwracają nazwy o niejasnej proweniencji: operatywka (SSP) - prawdopodobnie od przenośnego sensu wyrazu operatywny 'zaradny, działający energicznie, sprawnie i skutecznie', odżywka (SGU, SSP) - być może w wyniku metaforycznego użycia słowa (prymarnie 'środek kosmetyczny lub spożywczy, działający wzmacniająco').

Ciekawe tło dla funkcjonujących w polszczyźnie nazw prezerwatywy stanowią określenia występujące w innych językach. I tak:

- w potocznej angielszczyźnie występują: johnny $\leftarrow$ John ‘imię męskie: Jan’ (SSIPA), jimmy $\leftarrow$ Jimmy $\leftarrow$ James ‘imię męskie: Jakub’ (EWAP), Jimmy hatl Jimmy cap ‘czapka Jimmiego' (EWAP), connie $\leftarrow$ 'imię żeńskie: Connie' (SSIPA), franger $\leftarrow$ french letter 'francuski list' (SSIPA), merry widow 'wesoła wdowa' (od XIX-wiecznej marki prezerwatyw - Merry Widow, EWAP) rubber 'guma' (SSIPA), party hat 'czapeczka imprezowa w kształcie stożka' (SSIPA), bag 'torebka' (SSIPA, EWAP), jimjams 'piżamka' (SSIPA), safe 'sejf, kasa pancerna' (SSIPA), scumbag 'kanalia, drań' (SSIPA);

- w języku francuskim pojawiają się: pauch 'woreczek' (SSIPJF), paucha 'jw.' (SSIPJF), anglaise 'Angielka, angielski; pejs' (SSIPJF), cagoule 'czapka kominiarka' (SSIPJF), enveloppe 'koperta' (SSIPJF), capote 'kaptur, płaszcz' (SSIPJF, CNRTL), gumschwi 'guma' (SSIPJF), chapeau 'kapelusz, kask' (SSIPJF), capuchon 'skuwka, nasadka' (SSIPJF), poteau 
'maszt' (SSIPJF), remède 'lekarstwo' (CNRTL), antidote 'antidotum' (CNRTL), panacée 'panaceum' (CNRTL);

- w niemczyźnie natknąć się można na miana: überzieher 'palto, płaszcz, pokrowiec' (SSIPJN), lümmeltüte $\leftarrow$ Lümmel 'prosty człowiek; przenośnie: penis' + Tüte 'tutka, zwijka, torebka' (SSIPJN), gummi 'guma', präser $\leftarrow$ Präservativ 'prezerwatywa' (SSIPJN);

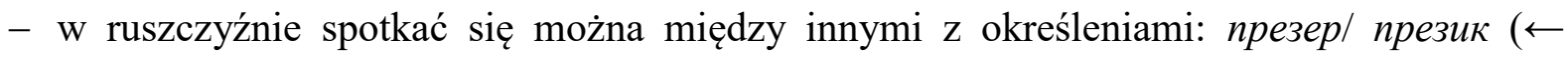
презерватив 'prezerwatywa', Bss), резинка 'gumka' (Bss, TsRż), галош/ калоша 'kalosz' (KA, TSRŻ), абажур 'abażur' (TSRŻ, Rż), резиновый мешочек 'gumоwy koszyk' (np.: https://ru.wikipedia.org/wiki/Презерватив [14 XI 2017]), рубашка 'koszula' (TsRŻ), саркофаг 'sarkofag' (np.: https://pikabu.ru/story/prezervativ_5457858 [14 XI 2017]), скафандр 'skafander' (TSRŻ);

- w językach czeskim i słowackim występują z kolei: gumička 'gumka' (np.: http://www.pluska.sk/izdravie/intimne/sex/alergia-latex-znamena-ziadne-kondomy.html) [14 XI 2017]), šprcguma 'gumowa szpryca' ( $\leftarrow \check{s p r}$ [iy]c 'wstrzykiwanie', Ls), šprcka 'jw.' (Ls), čiapočka 'jarmułka, czapka' (https://magazin.centrum.sk/sex-a-flirt/frcgumakondom-ciapocka-co-o-nich-viete/674761.html [14 XI 2017]), čepička 'czapka, kapturek' (SNCZ), kotón 'bawełna', olal olačka $\leftarrow$ 'Ola-Gum - marka czeskich prezerwatyw' (SNCZ), hladká pneumatika 'łysa/śliska opona' (SNCZ), gumídek 'gumowy, żelowy miś' (np.: www.aids-hiv.cz/materialy/9-kondom-listy-A6.pdf [14 XI 2017]), gumák 'nieprzemakalny płaszcz' (np.: www.aids-hiv.cz/materialy/9-kondom-listy-A6.pdf [14 XI 2017]), pláštěnka lásky 'płaszcz miłości' (np.: www.aids-hiv.cz/materialy/9-kondom-listy-A6.pdf [14 XI 2017]).

Jak wynika z przedstawionych nazw, zarówno w języku polskim, jak też w innych językach, wiele nazw wprost lub pośrednio odnosi się do materiału, z jakiego wykonana jest prezerwatywa - lateksu, czyli pochodnej kauczuków, potocznie utożsamianego z gumą: pol., czes. gumal ang. rubber/ franc. gumschwi/ ros. желательная резинка/ niem. Guтmi ('elastyczna masa będąca produktem wulkanizacji kauczuku'), ogumienie ('opony osłony na koła pojazdu'), czes. hladká pneumatika 'łysa/śliska opona', pol. gumiak ('obuwie z gumy’), pol. kalosz ('gumowe buty'), pol. opona ('gumowa osłona na koła pojazdu'), pol. lateksówa (Kołodziejek 2005: 186), pol. presguma (SGU, STGP).

Wyraźna większość potocznych określeń prezerwatywy ma proweniencję XX-wieczną. Niektóre z nich mogą mieć jednak starszy rodowód i być pożyczkami semantycznymi; chodzi tu przede wszystkim o pol. guma, które na początku minionego wieku pojawiło się 
w reklamach prasowych, i ang. rubber, które funkcjonowało w od połowy XIX wieku (wraz z pojawieniem się pierwszych wulkanizowanych prezerwatyw) (Collier 2007: 134-135, 157). Niemniej jednak poza najstarszymi określeniami: prezerwatywa i kondom, mającymi charakter internacjonalizmów, należą one do rejestru polszczyzny potocznej (podobnie jak w wielu innych językach, w których uznawane są za kolokwializmy).

\section{Uwagi końcowe}

Przedstawiony materiał dowodzi, że wspomniane na wstępie rozluźnienie obyczajowe nie oznacza bynajmniej wyjścia poza sferę tabu: wbrew pozorom fakt swobody mówienia na tematy uznawane za „wstydliwe” nie przyniósł detabuizacji w sferze języka. Przeciwnie nieskrępowane poruszanie zagadnień seksu i seksualności idzie w parze z poszerzaniem zasobu eufemistycznego słownictwa związanego z życiem intymnym. Od XX wieku sukcesywnie pojawiają się coraz to nowe określenia wcale nienowych zachowań i przedmiotów. Oczywiście, różne są źródła tych eufemistycznych określeń - przede wszystkim jednak nadal wiążą się ze wstydem, rzadziej (w ograniczonych sytuacjach) mają motywację towarzyskoetykietalną (Dąbrowska 1992: 124). Trzeba przy tym wyrazić przekonanie, że to dobry znak, wszakże ,zanik tabu we współczesnej kulturze uważany jest za jedno z najniebezpieczniejszych zjawisk [...], aby cywilizacja trwała, konieczne jest poszanowanie dla różnego rodzaju tabu" (Dąbrowska 1993: 20).

\section{Przypisy}

${ }^{1}$ Zakładam przy tym za Anną Dąbrowską, że ,tabu jest zjawiskiem kulturowym obejmującym wszystko to, co jest objęte zakazem społecznym (czasem również prawnym); są to zachowania, których nie należy praktykować, i tematy, jakich nie należy poruszać w danej społeczności (nie wypada o nich mówić), ponieważ są uznawane za wstydliwe, niebezpieczne, kontrowersyjne, przykre lub niemoralne” (Dąbrowska 2008: 175).

${ }^{2}$ Szerzej na temat samego tabu wypowiada się etnolog i antropolog kultury Jerzy Sławomir Wasilewski, pisząc między innymi, że „tabu jest zespołem postaw o bardzo niejednorodnej i wewnętrznie sprzecznej charakterystyce" (Wasilewski 2010: 11).

${ }^{3} \mathrm{~K}$ woli ścisłości wypada dodać, że to węższe znaczenie, przejęte z francuszczyzny, niemal równolegle pojawiło się też w wielu innych językach - tak jest m.in. w angielskim (OETYMD) i niemieckim (EWDS). Interesujące, że słowniki francusko-polskie z 1848 r. i 1858 r. notują jeszcze tylko ogólne znaczenie: „Preservatif, ive, $a$. zapobiegający czemu. =, s. m. prezerwatywa, środek zapobiegający - ochrona od..." (Janusz [red.] 1848: 505), „PREZERWATYWA, y, s. $f$. presrvatif, preservativ contre qu chose, ob. ZAPOBIEŻENIE, OCHRONA, ŚRODEK” (Kazimirski [red.] 1858: 457).

4 Jako XIX-wieczna pożyczka z języka angielskiego wyraz kondom pojawia się również w niemczyźnie (EWDS).

${ }^{5} \mathrm{Na}$ taki trop prowadzi opowieść Johanna Prokscha Prevention of Venereal Diseases z 1872 roku (zob. Hendrickson 2000: 199-200).

${ }^{6}$ Co ciekawe, fałsz tej teorii znany był w Polsce w pierwszych dziesięcioleciach XX wieku: „Kondon (prezerwatywa). Jest to najdawniejszy i dziś jeszcze bez wątpienia najlepszy i najpewniejszy sztuczny środek ochron- 
ny. Używany już w starożytności, został w 16. wieku przez włoskiego lekarza Fallopis znowu zalecony, nie jest więc wynalazkiem jakiegoś lekarza »Condona«, od którego rzekomo pochodzi nazwa jego, pozostaje raczej w związku z miastem francuskiem »Condom«. H. Ferdy przypuszcza, że słowo to pochodzi od słowa »condus«, t. zn. ten, który coś ukrywa, i że powinno właściwie brzmieć »condus« zamiast »kondom«” (Bloch 1929: 241).

\section{Wykaz skrótów użytych w tekście}

BSS - Кожевников, Александр Ю. (ред.) (2003) Большой синонимический словарь русского языка. Санкт-Петербург: Нева.

CED - Hanks, Patrick (red.) (2012) Collins English Dictionary. London: Collins.

CNRTL - Centre National de Ressources Textuelles et Lexicales. http://www.cnrtl.fr/synonymie/. 12.08.2017.

DAF - Druon, Maurice, Carrère d'Encausse, Hélène (red.) (2011) Dictionnaires de l'Académie française. 9ème édition. Vol. 3. Paris: Imprimerie nationale, Fayard.

EINT - Encyklopedia Internautica. encyklopedia.interia.p1/. 8.07.2017.

Eswo - Lam, Stanisław (red.), Brückner, Aleksander (przedm.) (1939) Encyklopedyczny słownik wyrazów obcych. Warszawa: Księgarnia Wydawnicza Trzaski, Everta i Michalskiego.

EWAP - Hendrickson, Robert (red.) (2000) The Facts on File Encyclopedia of Word and Phrase Origins. New York: Facts On File.

EWDS - Kluge, Friedrich (red.) (2001) Etymologisches Wörterbuch der deutschen Sprache. Berlin - New York: Walter de Gruyter.

КА - Сосновский, Александр (ред.) (2000) Корпус аморис. Энщиклопедический толковый словарь сексуальности, Москва: Терра.

KNAP - Knapiusz, Grzegorz (Cnapius) (1621) Thesaurus polono-latino-graecus seu promptuarium lingua Latinae et Graece [...]. Cracoviæ: Typis \& Sumptu Francisci Caesarij.

Ls - Knížek, Jeroným (red.) Lidový slovník pro chalupáře. http://lidovyslovnik.cz/. 11.07.2017.

MssIMP - Miejski słownik slangu i mowy potocznej. http://www.miejski.pl/. 8.07.2017.

MswoIT - Pawelec, Radosław (red.) (2003) Młodzieżowy słownik wyrazów obcych i trudnych. Warszawa: Wilga.

NKJP - Narodowy Korpus Języka Polskiego. http://nkjp.pl/. 10-12.07.2017.

OETYMD - Harper, Douglas (red.) Online Etymology Dictionary, http://www.etymonline.com/. 12.07.2017. 
Rż - Зугумов, Заур (ред.) (2015) Русскоязычный жаргон. Историко-этимологический толковый словарь преступного мира. Москва: Книжный мир.

SDoR - Doroszewski, Witold (red.) (1958-1969) Stownik języka polskiego. T. I-XI. Warszawa: Państwowe Wydawnictwo Naukowe.

SGU - Zgółkowa, Halina (red.) (2004) Nowy słownik gwary uczniowskiej. Wrocław: Europa.

SL - Linde, Samuel B. (red.) (1807-1814) Stownik języka polskiego. Warszawa: Drukarnia Zakładu Ossolińskich.

SNCZ - Hugo, J. (red.) (2009) Slovník nespisovné češtiny. Praha: Maxdorf.

SPLP - Lubaś, Władysław (red.) (2001-2003) Słownik polskich leksemów potocznych. Wrocław: Dolnośląskie Wydawnictwo Naukowe.

SPP - Czeszewski, Maciej (red.) (2008) Słownik polszczyzny potocznej. Warszawa: Wydawnictwo Naukowe PWN.

SSIPA - [Opr. zespół] (2014) WAZZUP? Słownik slangu i potocznej angielszczyzny. Kraków: Lingea Sp. z o.o.

SSIPJF - [Opr. zespół] (2014) PAS DE BLEME! Słownik slangu i potocznego języka francuskiego. Kraków: Lingea Sp. z o.o.

SSIPJN - [Opr. zespół] (2014) IS' WAS? Słownik slangu i potocznego języka niemieckiego. Kraków: Lingea Sp. z o.o.

SsM - Czeszewski, Maciej (red.) (2001) Słownik slangu młodzieżowego. Piła: Ekolog.

SSP - Lewinson, Jacek (red.) (1999) Słownik seksualizmów polskich. Warszawa: Książka i Wiedza.

STGP - Stępniak, Klemens (red.) (1993) Słownik tajemnych gwar przestęczych. Londyn: Puls.

SW - Karłowicz, Jan, Kryński, Adam A., Niedźwiedzki, Władysław (red.) (1900-1927) Słownik języka polskiego. T. I-VIII. Warszawa: Nakładem prenumeratorów i Kasy im. Mianowskiego.

SWIL - Zdanowicz, Adam, Szyszko, Michał B., Filipowicz J. i in. (red.) (1861) Słownik języka polskiego [...] do podręcznego użytku. Wilno: Nakładem Maurycego Orgelbranda.

SwoA - Arct, Michał (red.) (1886) Słownik wyrazów obcych. Warszawa: Nakład i własność Michała Arcta.

SwoE - Kamińska-Szmaj, Irena (red.) (2001) Słownik wyrazów obcych. Wrocław: Europa.

SwoK - Kopaliński, Władysław (red.) (2014) Słownik wyrazów obcych i zwrotów obcojęzycznych z almanachem. Warszawa: Oficyna Wydawnicza Rytm.

SwoKA - Karłowicz, Jan (red.) (1895) Słownik wyrazów obcego a mniej jasnego pochodzenia używanych w języku polskim. Kraków: Nakładem autora. 
SzA - E. Mańczak-Wohlfeld (red.) (2010), Słownik zapożyczeń angielskich w polszczyźnie. Warszawa: PWN.

SXVI - Mayenowa, Maria R., Pepłowski, Franciszek, i in. (red.) (1966-1994, 1995-) Słownik polszczyzny XVI wieku. Wrocław - Warszawa: Ossolineum - Instytut Badań Literackich PAN.

SXVII - Koneczna, Halina, Skorupka, Stanisław, Szlifersztejnowa, Salomea, Siekierska, Krystyna, Gruszczyński, Włodziemierz (red.) (1996-) Słownik języka polskiego XVII i 1. połowy XVIII wieku. Kraków: Instytut Języka Polskiego PAN.

TLF - Quemada, Bernard (red.) (1988) Trésor de la langue française. Vol. 13. Paris: Editions du Centre National de la Recherche Scientifique.

TrOTZ - Trotz, Michał A. (red.) (1764) Nowy dykcyonarz to iest Mownik polsko-niemieckofrancuski, z przydatkiem przysłów potocznych, przestrog gramatycznych, lekarskich, matematycznych, fortyfikacyynych, żeglaskich, łowczych i inszym naukom przyzwoitych wyrazow. Lipsk: Nakładem Iana Fryderyka Gledycza [i.e. Officina Gleditschiana].

TSRŻ - Грачёв, Михаил А. (ред.) (2006) Толковый словарь русского жаргона. Москва: Юнвес.

USJP - Dubisz, Stanisław (red.) (2003) Uniwersalny słownik języka polskiego. T. 1-4. Warszawa: Wydawnictwo Naukowe PWN.

WswoIT - Markowski, Andrzej, Pawelec, Radosław (red.) (2001) Wielki słownik wyrazów obcych i trudnych. Warszawa: Wilga.

ŻK - Żargon kierowców ciężarówek. http//truckfocus.pl/. 8.07.2017/Słowniczek - slang CB. www.cb-mania.pl. 8.07.2017.

\section{Bibliografia}

Bańko, Mirosław (2003) Mały słownik wyrazów kłopotliwych. Warszawa: Wydawnictwo Naukowe PWN.

Bloch, Iwan ([1907]1929) Życie ptciowe naszych czasów [Das Sexualleben unserer Zeit in seinen Beziehungen zur modernen Kultur, Berlin: L. Marcus]. (tłum.) Z. Bass. Lwów: Dr Maksymiljan Bodek. Księgarnia Nakładowa.

Collier, Aine (2007) The Humble Little Condom. A History. New York: Chelsea House Publishing.

Cryer, Max (2014) Is It True? The facts behind the things we have been told. Auckland: Exisle Publishing. 
Dąbrowska, Anna (1992) „Eufemizmy mowy potocznej”. [W:] Anusiewicz Janusz, Nieckula Franciszek (red.) Język a kultura. Tom 5: Potoczność w języku i kulturze. Wrocław: Wydawnictwo Uniwersytetu Wrocławskiego; 117-178.

Dąbrowska, Anna (1993) Eufemizmy wspótczesnego języka polskiego. Wrocław: Wydawnictwo Uniwersytetu Wrocławskiego.

Dąbrowska, Anna (1998) Słownik eufemizmów polskich, czyli w rzeczy mocno, w sposobie łagodnie. Warszawa: Wydawnictwo Naukowe PWN.

Dąbrowska, Anna (2008) „Zmiany obszarów podlegających tabu we współczesnej kulturze”. [W:] Dąbrowska Anna (red.) Język a kultura. Tom 21: Tabu w języku i kulturze. Wrocław: Wydawnictwo Uniwersytetu Wrocławskiego; 173-196.

Dłużniewski, Marceli (1855) Wyjawienie sposobu leczenia cholery bez wzywania lekarza, oraz sposobu uchronienia się przed nią. Lwów: Drukiem i nakładem M.F. Poremby.

Dubisz, Stanisław (1999) „Tytułem przedmowy - o seksie i seksualizmach” [W:] Lewinson, Jacek (1999) Słownik seksualizmów polskich. Warszawa: Książka i Wiedza; VI.

Giddens, Anthony ([1992]2005) Przemiany intymności. Seksualność, miłość i erotyzm we wspótczesnym społeczeństwie [Sexuality, Love, and Eroticism in Modern Societies. Cambridge: Polity Press] (tłum.) Alina Szulżycka. Warszawa: Wydawnictwo Naukowe PWN.

Giedroyć, Franciszek (1931) Polski słownik lekarski. T. 1, A-Ó. Warszawa: Wydawnictwo Kasy im. Mianowskiego, Instytutu Popierania Nauki.

Giedroyć, Franciszek (1933) Polski stownik lekarski. T. 2, P-Z. Warszawa: Wydawnictwo Kasy im. Mianowskiego, Instytutu Popierania Nauki.

Grotjahn, Alfred (1930) Higjena ludzkiego rozrodu. Zarys praktycznej eugeniki. (red.) Janiszewski T. Warszawa: Polskie Towarzystwo Eugeniczne.

Hendrickson, Robert (2000) The Facts on File Encyclopedia of Word and Phrase Origins. New York: Checker Books.

Janicki, Kamil (2015) Epoka hipokryzji. Seks i erotyka w przedwojennej Polsce. Kraków: Znak.

Janusz, W. [brak imienia] (red.) (1848) Dokładny słownik francusko-polski podtug najlepszych źródeł. Lwów: Nakładem E. Winiarza.

Kazimirski, Wojciech (red.) (1858) Dictionnaire français-polonais = Słownik francuzkopolski. Berlin: Księgarnia B. Behra.

Kołodziejek, Ewa (2005) Człowiek i świat w języku subkultur. Szczecin: Wydawnictwo Naukowe Uniwersytetu Szczecińskiego. 
Kruck, William E. (1981) „Looking for Dr Condom”. Publication of the American Dialect Society. 66; 1-105.

Kurkiewicz, Stanisław (1906), Z docieków (studyów) nad życiem ptciowem luźne osnowy (tematy). 2. Szczegółowe odróżnienie czynności płciowych. Kraków: Drukarnia Związkowa. McNair Brian ([2002]2004) Seks, demokratyzacja pożądania i media, czyli kultura obnażania [Striptease Culture: Sex, Media and the Democratization of Desire. Routlegde] (thum.) Ewa Klekot. Warszawa: Muza.

Mieder, Wolfgang (1987) „Kondom - ein altes/neues Wort geht um. Eine etymologische Skizze". Sprachspiegel. 43; 99-108.

Pacuła, Jarosław (2014) „O boskim doznaniu (erotycznym), anielskich przeżyciach (seksualnych) i świętym zakazie (pracy po godzinach). Z zagadnień profanizacji słownictwa religijnego". Świat i Stowo. 2(23); 285-312.

Polkowski [brak imienia] (1853) O cholerze. Warszawa: Drukarnia J. Jaworskiego.

Przybylska, Renata (1987) „Współczesne polskie słownictwo erotyczne”. [W:] Preyzner Marcin (red.) Język. Teoria-Dydaktyka. Materiały VIII Konferencji Młodych JęzykoznawcówDydaktyków. Karpacz, 3-6 III 1983. Kielce: Wyższa Szkoła Pedagogiczna; 97-110.

Raudnitz, Leopold (1865) Siły leczące i skutki styryjskiego soku z ziół oraz zastosowanie tegoż szczegółowe do leczenia różnych chorób, (tłum. J. Spittal). Lwów: Drukarnia E. Winiarza.

Rosenblum, Beniamin (1843) Przewodnik lekarski dla mężczyzn, czyli zbiór wiadomości i rad dotyczacych aktu miłości fizycznej, skutków jej nadużycia, chorób wenerycznych, środków ustrzeżenia się od nich; niemocy męskiej, jej przyczyn i sposobów leczenia. Warszawa: Nakładem S. Orgelbranda.

Thundy, Zaharias P. (1985), ,The Etymology of Condom”. American Speech. 60(2); 177-179.

Wasilewski, Jerzy S. (2010) Tabu. Warszawa: Wydawnictwa Uniwersytetu Warszawskiego.

Youssef, Henry (1993) „The History of the Condom”. Journal of the Royal Society of Medicine. $86 ; 226-228$. 